\title{
The Tectonics of the Turn of the Millennia: Notes at the Margins of the Text and the Intertextual Field of Anatoly Chmykhalo's Works
}

\author{
Olga A. Karlova* \\ Siberian Federal University \\ 79 Svobodny, Krasnoyarsk, 660041, Russia
}

Received 12.09.2014, received in revised form 09.10.2014, accepted 12.11.2014

The article is devoted to the culture and literature analysis of the artistic-stylistic dynamics of the creativity of the famous Russian writer Anatoly Chmykhalo in the context of the $20^{\text {th }}-21^{\text {st }}$ centuries.

Keywords: realism (social, psychological, mythological-historical), modernism, postmodernism, metanovel, simulacrum, model extrapolation.

Research area: Theory and History of Culture.

Anatoly Chmykhalo, a famous Russian military writer, a master of the historical prose, was born in 1924. He fought during World War II, was wounded twice and was contused. After the war, he gained significant experience in journalism and theatre. Anatoly Chmykhalo passed away in March 2013. He was 89 years old, had a son and a daughter, two grandsons and even a great grandson. A true Siberian hero, a founder and a witness of life of four generations.

Hence, he got many more children: 15 books in different genres, 9 of them were novels. What were they like, these literature creations separated from each other by quite significant periods of real life? How did the creative activity of the writer respond to the large-scale social changes of Stalin's times - from "thawing" to "stagnation", from thereon to Gorbachev's perestroika, Eltsyn's "shock therapy" and from thereon to strengthening of Russian statehood in Putin's times? Four generations represent four worldviews, four different understandings of the world. It is an indisputable change of the writer's worldview and styles - from socialist realism to late postmodernism.

Anatoly Chmykhalo entered the Russian Soviet literature in the 50s. In 1949 "October" magazine published a series of his verses, later on, his collections of verses were published: "Fellow-countrymen" (1951), "Steppe Summer Lightnings" (1954) and "Harvest Time" (1955). These verses and a subsequent novel "We Should Believe" of 1963 and a story "Quagmire" (1964) became his tribute to the writer's style and the epoch, during which the author was formed as a writer. They contain a Soviet dream the post-war

(c) Siberian Federal University. All rights reserved

* Corresponding author E-mail address: pr_karlova@krskstate.ru 
generation was inspired with, keenness on the images of strong-willed people with the Siberian character, capable for large-scale actions and strong feelings, the cult of overcoming - life, natural forces, themselves.

Nevertheless, in these years Anatoly Chmykhalo was busy with translation of his Khakass fairy-tales, work on the libretto to the national Khakass opera. Turning to the origins of the national character, journalist's experience, thoughts of his first historical novel and search for the material to it bring the writer-historian far beyond the limits of what is allowed by the ideology.

In 1959 "High Water" is published, a novel where folklore-household and historicalpsychological reliability gets the upper hand over the ideological scheme. Such are vivid ambiguous images of Roman and Iakov, Domna and Makar Artem'ich, Niurka and Liuba, granny Lopatenchikha and grandpa Guzyr'. The latter, being sharp-tongued and humorously estimating bitter life, only at the first sight seems alike to the grandpa Shchukar' from Sholokhov's "Virgin Soil Upturned". In fact, it is an absolutely different image of the "male philosopher": another measure of life's bitterness and despair, as well as resistance, which transfers him from a comic character and adviser into a hero ready to sacrifice himself for others. Assessing the novel in the spirit of $60 \mathrm{~s}$ and praising the author for "opening new, interesting events and people's characters of the Civil War period and establishment of the Soviet power in Siberia", the classic of the socialist realism Boris Polevoi could not but emphasize: "the author is strong in knowing the material, everyday life, feeling of the common people and feeling of the word. It is a strong interesting book. The action carries the reader away over the whole 800 pages. The novel is muscular, absolutely healthy, not water bewitched" (Chmykhalo, A. "High Water". Novel. Book One. Altai Book Publishing House,
Barnaul, 1959. - p. 4.) The complexity of fictional and psychological fabric of this novel by Anatoly Chmykhalo will appear in the image of the Kyrgyz shepherd Zhiunuski, the first out of the long and vivid raw of future portraits of "indigenous dwellers", and in the intelligent rushing between the principles and humanness of Socialistrevolutionary Riazanov. And of course, in terms of innovative de-ideologization, the images of Kolchak and Anna Timireva, the real meeting with whom in faraway Rybinsk became fateful for the young talented writer. This encounter with an already old, but truly legendary woman, a princess, nee Safonova, the daughter of the director of the Moscow Conservatory, who went deep into Siberia after her beloved one - Admiral Alexander Kolchak, a polar explorer and a navigator, a scientist and a poet, a Russian officer and by the will of fate, "the Supreme Governor of Siberia", had turned a lot in the opinion and worldview of Anatoly Chmykhalo: "she was my bright sun ... I do not know who would I be, if not her"- he would say later. In "High Water", Anatoly Chmykhalo for the first time set foot on the "neutral zone" set by history between the "red" and the "white", "friend or foe" - and kept returning to the understanding of this national disaster, many years later.

Schemes were hacked, life broke into the novel.

The writer finally broke with socialist realism when he wrote "Three Springs", an autobiographical and military novel, in 1969. Long before the debates about "open - closed socialist realism", before legendary books by Chingiz Aitmatov and the generation of "the sixties", which marked the beginning of the literary discussion, about the same time with the artistic experience of Fiodor Abramov, Sergei Smirnov, Sergei Markov, Mikhail Dudin, who he knew and loved as friends and talented colleagues, Anatoly Chmykhalo finally came to realism. 
The novelty of the novel "Three Springs" is also confirmed by the fact that autobiographical work about the war was cut by censorship almost by one third. The war in the novel was shown cruelly, the truth was naked and did not fit the ideological schemes - the writer made this not in the 90s open for reevaluation, when all of us were enthusiastically opening the "blank spots" of history and rethinking the events that took place half a century ago. This was a generation earlier - in deep ideologized 1969.

The same revelation for early 80's was a tragically colourful image of the Ataman Soloviov, a Siberian Cossack marked in those years by a seemingly indelible feature of a gangster and anarchist. It was difficult to raise a question of the historical content of the time in 1981, four years before the Plenum of Gorbachev's perestroika, especially when it came to the epoch with sharp ideological assessments and heroes sanctified by ideology. The novel became an ethnophilosophical extension of the "High Water" and the historical dilogy devoted to the events of the 17th century on the banks of the Yenisei ("Wild Blood", 1974 and "Disgraced Land", 1977), very logical for the writer. Planning the third part of the historical epic, which he wanted to call "Cossack Children", Anatoly Chmykhalo, having found in the archives of the KGB a portfolio "about the gang" of Ivan Soloviov, soon gives up this idea. Having written the "Postponed Shot" based on interviews and documents from the KGB archives, having purged them in a convincing fiction, he therefore completed the development of the theme of the Cossack children's fate in Siberia. As if in the life drama of the Cossack ataman the main thing was said, the writer was approaching in his reflections from the seventeenth century to the present.

Killing this truly epic hero at the end of the novel is a symbol of something forced, in some way, a voluntary suicide of the Russian people.
The fight of Ivan with with Sidor Dyshlakov, a terrible product of "Revolution", grows into the symbol of the eternal biblical battle between two powers: the power capable to create and the power capable only to destroy. The drama of the epoch is that the latter wins. Like any real tragedy, the tragedy of Ivan is not in his physical death. Ivan did not seek the truth, he had one. And he could not get away from it, as he could not leave the land, where he was born, became the Cossack, into which he would be untimely buried, rejected and misunderstood like Hamlet.

The stages in the development of the main theme of his novels typical for the creativity of Anatoly Chmykhalo allow to speak about the historical metanovel of the writer (Karlova O.A. The Problem of Historical and Artistic Truth in the Novels of Anatoly Chmykhalo / Historical Prose and Literary-Historical Concept of Modernity. Proceedings of the Conference, Achinsk -Krasnoyarsk, 1996.- pp.34-38). The core of his creativity goes back to the philosophical, ontological idea - the idea of the battle of the free will of the man with the tragic course of history.

Today, at Soloviov's grave there is a cross, and in Irkutsk - there is a monument to Kolchak. Today, having perceived the historical truth, we consider familiar and understandable everything that in the 60 s and 70 s required truly civil and spiritual deeds. The flow of the historical and political revelations of the 90 s gave the illusion of the original universal knowledge to many people. It has got somehow forgotten that the change of the state ideology was not a miracle. And from this point of view, the creativity of Anatoly Chmykhalo in the 60s-70s can be defined in many ways as a forerunner of historical and literary revelations of the perestroika period. In his realistic works of the Soviet period, the person is not identical neither with the notion of "enemy", nor with the notion of the "positive protagonist". 
He is either more humane than his social destiny, or less than his humanness ...

Historical novels about the establishment of Krasnoyarsk are also written by the author in the dominant realistic manner. The realism school has provided Anatoly Chmykhalo's creativity with a scale, verified the accuracy of the language means, has given it the striking sharpness of historical details. But this was no longer the classical realism of Chekhov or Leo Tolstoy. Chmykhalo, as well as other talented Russian writers of this time, opens up new sides of realism, and above all psychological and historical-mythological. Novels are interesting for research not only to historians, but also anthropologists, ethnopsychologists, folklore and culture researchers, and socio-linguists. We see a clash of motives, ethnicities, cultures, in the historic and artistic canvas, "cross-linked" in the mythological-realistic manner with the use of linguistic means. This is a sign of modernism. Realist writers - each one of them in his/her own way - were solving the problem of reconstruction of historical colour in their texts. Thus, in A.K. Tolstoy's works the archaization of language is almost absent, A. Chapygin prefers a "language game in animosities", A.N. Tolstoy uses language elements of the depicted era (L.G. Samotik in the study "The Dictionary of the Historical Prose of A.I. Chmykhalo", Krasnoyarsk, 1999, examines these problems in detail.) Anatoly Chmykhalo chooses a completely original way to achieve the historical flavour: in the text there is no outdated vocabulary and archaic grammar forms. The writer creates a text, which is a historical simulacrum, without using the language data of the seventeenth century. And if there are rarely used words implanted in the text (archaisms, historicisms, dialectic words, barbarisms, exotic words, animosities and codified vocabulary), and there are a lot of them in the text, their game is tied to a clear context, and their scattering is mosaic in the modernism manner and explained to be understood by any reader.

The novels in full compliance with the prevailing spirit of Siberia - the spirit of the crossing of cultures and civilizations - are focused on the fates of representatives of different ethnic groups, different social strata. Many of them are presented in enfilade projection connecting the unconnected, which is very typical for the modernist neo-baroque. The novelist reconstructs the historical reality using not only archival materials of Russian museums and research institutes, the unique ancient texts from the storage houses of Mongolia, Kyrgyzstan, Kazakhstan and Ukraine, but also using the method of model-psychological extrapolation: he finds the descendants of those Cossacks who came to the banks of the Yenisei River in ancient times, and explores the psychological, cultural and portrait characteristics of this particular group. And where from would modernism appear in Soviet Siberia of the 80s and, moreover, based on historical materials? But it is the threecenturies deep history, Siberia with its genes for freedom and the trend of concepts of industrial modernism in the contemporary society that become the mighty wind beneath the wings of Anatoly Chmykhalo's fantasy.

It may seem that the writing style is perfect already. Themajor, even epic-historical works have been written. We are at the end of the twentieth century. And Anatoly Chmykhalo immerses in the reflection of the past century. The reflection of the outgoing epoch is a feature of creativity of a considerable amount of writers. But it is not enough to just pay the tribute to the epoch. Not only to capture the spirit of the turning point in the content of the era, but also to recreate it in an artistic form - this is an obvious feature of the great talent. Thus, the two volumes were written by Chmykhalo: "In the Realm of Freedom: Dilogy in Verse and Prose" (2007). After 800-page 
novels, "mini-novels in episodes" for 2-3 pages, interspersed with "thinking out loud" and "poetry on occasion", represent obvious postmodernism. "A Night Without Sleep" and "Lamentation for Russia" are brilliant examples of postmodernism with its conciseness and contrasts, clips (art "cutting") of scenes, associations, impressions; light, moving as if on the surface of the plot and images, writer's story, always ending with an emotional "blow", recreating a kind of a "rhythm that is hidden in the life of mankind". In these novels the individual freedom of the human and, at the same time, his reflective solitude are shown (N.M.Smirnova. Modernism/Global Studies. Moscow, St. Petersburg, New York, 2006), the value of the dual connection with the culture-forming beginning and at the same time the priority of the individual search for truth. This value professed by the writer has been suffered throughout his creative destiny, but it is surprisingly modern in the epoch of establishment of the doctrine of personal rights priority in Russia and simultaneously the dramatic awareness of the impossibility of such a "personal paradise". In the works by Chmykhalo, man is immanent to modernism - he is still an actor. But at the same time, he is an actor of postmodernism, conscious of the reality of the impending ecological and anthropological catastrophe of the world, a rebel against the spiritual impoverishment of Russia, ready for the confession and repentance of his generation - generation of Founders and Enthusiasts.
His "Obscene Poetry" and "Naughty Verses", which he calls "nuggets" (as if primordial elements of the natural and human existence) and "placers" (available for everyone and being under our feet, as the truth being spawn like beads under the feet of the crowd by single thinkers) - this is the confession of the Man and the Generations covered a little with a veil of irony and selfirony.

... We perceive human life as a kind of continuity, and the man himself as an absolute integrity between two dates of birth and death. Only at a considerable historical distance it is possible to see cultural tectonic shifts at the turn of the centuries: the changes of civilizational features, cultural symbols, and the changes of the dominant view of the world become so obvious then, to say nothing about the turn of the millennia! Someday scientists will quite convincingly prove that people of the $20^{\text {th }}$ century were different from the people of the $21^{\text {st }}$ century, like for example, Neanderthals were different from Cro-Magnons....

Nevertheless, the truth that the new sprouts in humans is also correct. However, not in everybody. Only in those individuals, who are endowed with the talent to stare intently into the Past and the Future, to reproduce on paper or canvas their insight and also endowed with the power not to cave in to the harsh present. It is this imprinted view of the historical distance that once becomes a projection of the present day ... 


\section{Тектоника рубежа тысячелетий:}

заметки на полях текста

и интертекстуального поля произведений

Анатолия Чмыхало

О.А. Карлова

Сибирский федеральный университет

Россия, 660041, Красноярск, пр. Свободный, 79

Статья посвящена культурологическому и литературоведческому анализу художественностилевой динамики творчества известного российского писателя Анатолия Чмыхало в контексте $X X-X X 1$ веков.

Ключевые слова: реализм (сочиалистический, психологический, мифоисторический), модернизм, постмодернизм, метароман, симулякр, модельная экстраполяция.

Научная специальность: 24.00.01 - теория и история культуры. 